\title{
Upper Gastrointestinal Series
}

National Cancer Institute

\section{Source}

National Cancer Institute. Upper Gastrointestinal Series. NCI Thesaurus. Code C17639.

An $\mathrm{x}$-ray examination of the esophagus, stomach and first part of the small intestine

following coating with barium solution via ingestion. 